\title{
O PROFESSOR DE ENFERMAGEM FRENTE ÀS TENDÊNCIAS PEDAGÓGICAS . UMA BREVE REFLEXÃO *
}

\section{THE TEACHING OF NURSING AND THE PEDAGOGIC TREND}

\author{
Myriam A. Mandetta Pettengill** \\ Lúcia Marta G. da Silva** \\ Mariusa Basso** \\ Beatriz H.R.A. Savonitti** \\ Isabel Cristina Vilela Soares**
}

PETTENGILL, M.A.M. et al. O professor de enfermagem frente às tendências pedagógicas. Uma breve reflexão. Rev.Esc.Enf.USP, v.32, n.1, p.16-26, abr. 1998 .

\begin{abstract}
RESUMO
As autoras fazem uma reflexão situando o professor de enfermagem nas diferentes abordagens pedagógicas ( Tradicional, Cognitivista, Comportamentalista, Humanista e Sócio-Cultural), com o objetivo de analisar sua aplicaşão no ensino de enfermagem, contribuindo para que o professor reflita sobre sua prática e a exerça de forma criativa e inovadora.
\end{abstract}

UNITERMOS: Enfermagem. Ensino. Teorias pedagógicas.

\begin{abstract}
This paper reviews important aspects about teaching nursing, in order to give nursing professionals an outline of the present pedagogical approaches (Traditional, Cognitivist, Behaviorist, Humanistic, Sociocultural), so that they can reflect upon their role as educators.
\end{abstract}

UNITERMS : Nursing. Pedagogical approaches. Education.

\section{INTRODUÇÃO}

Este trabalho surgiu da nossa inquietação quanto à pratica do docente de enfermagem, durante a disciplina Problemas do Ensino de Enfermagem, oferecida no programa de Pós-Graduação da Escola de Enfermagem da USP.

Nós enfermeiros, estamos sempre nos deparando com situações referentes ao processo de ensino, nos mais variados momentos, seja assistindo pacientes e promovendo educação para saúde; exercendo atividades administrativas junto à equipe de enfermagem e participando de programas de educação continuada e ainda, atuando diretamente no ensino contribuindo para a formação de futuros profissionais.
Questionamos se o enfermeiro ao término da graduação estaria instrumentalizado para exercer tais funções, uma vez que nos cursos, a ênfase é geralmente dada aos aspectos biologicos do processo de assistir o paciente, de acordo com o modelo biomédico hegemônico.

Desta forma, o enfermeiro assistencial, que por tendência ou opção pessoal, passa a exercer atividades docentes, o faz de maneira intuitiva, seguindo modelos que lhe foram significativos durante sua formação acadêmica. Segundo BIGGE (1977) "toda pessoa que ensina tem uma teoria de aprendizagem" seja ela solidamente assentada em bases teóricas da psicologia cientifica ou sobre suas crenças e valores.

\footnotetext{
" Trabalho apresentado à disciplina:" Problemas do ensino de Enfermagem”, do Programa de Pós-Graduação da EEUSP.

** Enfermeiras. Mestrandas do Programa de Pós-Graduação em Enfermagem da EEUSP
} 
Todas as ações de um professor são orientadas pela forma como vê o mundo, pelos objetivos que pretende atingir, pela sua concepção de educação etc. Entretanto, o professor nem sempre é capaz de explicitar claramente as teorias de aprendizagem que o influenciaram, muito embora um espectador experimentado possa identificá-las a partir da observação

Buscamos, através deste estudo, analisar as diferentes tendências pedagógicas, situando o professor de enfermagem dentro de cada uma delas, a fim de possibilitar que os enfermeiros se identifiquem em pelo menos uma dessas tendências e a partir daí procurem maior embasamento para sua prática docente.

Encontramos na literatura classificações propostas por LIBÂNEO (1982) e SAVIANI (1985) que serviram para nossa compreensão do assunto, porém optamos pelo referencial de MIZUKAMI (1986), pois facilita a apresentação pela maneira como classifica as diversas tendências.

A autora dividiu as tendências em 5 abordagens pedagógicas, sendo: Tradicional, Cognitivista, Comportamentalista, Humanista e Sócio-Cultural.

Segundo BIGGE(1977), é necessário salientar que dentre as diferentes teorias de aprendizagem, nenhuma, em particular, pode ser tomada como superior às outras em termos absolutos, sendo freqüente que o professor desenvolva uma forma de atuação a partir da contribuição de várias teorias.

Ver o professor de enfermagem sob o enfoque de cada tendência pedagógica nos permite refletir sobre cada uma delas. A reflexão sobre o problema nos leva à crítica do mesmo e segundo MORAES (1996) "examinar a crítica, analisá-la sob os diferentes ângulos em que é proposta e buscar sua superação: esta é a tarefa mais complexa. Do ângulo de docência, o ensino, exige reflexão importante. É preciso revitalizá-lo, pensálo em novas perspectivas."

Para o professor promover sua prática docente é necessário alto conhecimento técnico, reflexão constante e engajamento intelectual e afetivo. Deve estar sempre em busca de inovação, propondo novas formas de atuação que facilitem o aprendizado.

O relevante é que a atuação do educador seja coerente, consistente e adequada do ponto de vista educacional, o que pode ser alcançado após análise cuidadosa das teorias existentes bem como através do conhecimento e reflexão acerca do ambiente em que se processa o ensino e como ele é influenciado por estas teorias.

De acordo com o que foi exposto, nosso objetivo neste trabalho é:
- analisar as diferentes abordagens pedagogicas e sua aplicação no ensino de enfermagem, contribuindo para que o professor de enfermagem reflita sobre sua prática e a exerça de forma criativa e inovadora.

\section{METODOLOGIA}

Optamos por descrever, de forma sucinta, as abordagens pedag6gicas discutindo como tem sido utilizada no ensino de enfermagem e, na seqüência, apresentar um exemplo de situação prática do professor de enfermagem em cada uma delas, apontando, entre parêntesis, as principais características evidenciadas.

Durante a apresentação do trabalho na disciplina, tal exemplificação foi realizada através da técnica de dramatização, sendo solicitado aos participantes que observassem as características de cada abordagem e anotassem. Ao término, cada um relatava sua seqüência anotada e o que levou àquela suposição, gerando uma discussão no grupo.

\section{ABORDAGEM TRADICIONAL}

Para SNYDERS (1974), o ensino tradicional é o ensino verdadeiro, onde a atividade de ensinar está centrada no professor que a expõe e interpreta, conduzindo o aluno ao contato com as grandes realizações da humanidade e da cultura em geral. Para que isto ocorra, utiliza-se de meios como a apresentação de objetos, ilustrações e exemplos, contudo o principal método é a palavra, exposição oral da matéria a ser assimilada pelo aluno. Este tipo de ensino é voltado para o externo do aluno como: o programa, a disciplina, o professor, partindo do princípio que o aluno é um mero espectador que realiza somente o que lhe é mandado, por uma autoridade centrada em si mesma que é o professor.

Considera-se que o homem irá conhecer o mundo a partir das informações que receber durante o período de sua formação, sendo portanto um receptor passivo, e após assimilação do conteúdo, poderá repeti-lo a outras pessoas que ainda não dominem o assunto, sendo assim eficiente em sua profissão, quando de posse dessas informações e conteúdos.

$\mathrm{Na}$ abordagem tradicional a educação é considerada como um produto, pois os modelos já estão preestabelecidos, onde o processo ensino. aprendizagem está ausente, pois as idéias são selecionadas e organizadas logicamente. 
Supõe-se que o aluno ao ouvir e ao fazer exercícios repetitivos, irá automaticamente decorar a matéria para depois reproduzi-la através de chamada oral ou prova, cujo objetivo primordial é constatar que o aluno assimilou o mínimo exigido, para poder passar para uma nova etapa do ensino.

O objetivo implícito ou explícito deste tipo de ensino é o de formar um aluno ideal. É predominantemente dedutivo. Em geral, há uma decomposição da realidade onde a intenção é a de simplificar o ensino. As matérias são dadas de forma isolada, não levando em consideração os interesses do aluno, da sociedade e da vida como um todo. Baseia-se na apresentação de dados sensíveis, onde o aluno observa e constrói a imagem em sua mente. Mostrar objetos, gravuras, serve para melhor memorização do que é captado pelos sentidos.

O material concreto é mostrado, demonstrado, até mesmo tocado pelo aluno, mas não é repensado ou mesmo reelaborado pelo seu próprio pensamento.

Segundo MIZUKAMI (1986), para Chartier a escola é um local onde se raciocina, em que o ambiente deve ser austero para que o aluno não se distraia. Considera o ato de aprender como uma cerimônia e acha necessário que o professor se mantenha distante do aluno, ocorre uma relação vertical, onde o professor é considerado o detentor do saber e o aluno mero e passivo receptor.

No processo ensino-aprendizagem a ênfase é dada às situações vivenciadas em sala de aula, único local que se pode aprender e perpetuar as informações. Contudo, este tipo de método propicia a formação de reações estereotipadas, sem valor educativo vital, desprovido de significado social, inútil para a formação da capacidade intelectual e para formação do pensamento reflexivo, pois o desenvolvimento do raciocínio, está reduzido à prática de memorização.

A metodologia baseia-se com freqüência em aulas expositivas e em demonstrações do professor, tendo como medida de avaliação da aprendizagem, a reprodução do conteúdo pelo aluno. No caso de dúvidas em sala de aula, estas são sanadas individualmente, e o restante da classe não participa nem do questionamento feito pelo aluno e nem da explicação dada pelo professor. A ênfase não é dada ao educando, e sim ao professor com o intuito de garantir a aquisição do conteúdo cultural pelo aluno.

$O$ docente de enfermagem tem como objetivo centrar o aluno no "ser enfermeiro", inteirando-o e fazendo-o interagir no processo saúde/doença.

A natureza da enfermagem é complexa , contudo a natureza do professor de enfermagem o é ainda mais, pois um determinado grupo social (alunos de enfermagem) será formado pelo docente. Comportamentos e hábitos serão mudados no decorrer desta aprendizagem, ocorrendo uma interação entre o aluno e o professor, cujo objetivo é formar pessoas para desenvolver uma atividade específica na sociedade.

Observa-se contudo, que a maioria das escolas de enfermagem segue a tendência tradicional, onde o professor é o detentor do saber, tendo como resultado uma relação vertical entre professoraluno. O mesmo é observado na prática diária de enfermagem (enfermeiro-paciente), quando ambas deveriam ter uma relação horizontal. Acreditamos portanto que está na hora de repensarmos sobre a necessidade de mudanças no processo de ensino de enfermagem, contemplando de forma mais concreta e real os interesses e necessidades dos alunos de enfermagem, que nem sempre são ouvidos ou observados pelo docente que segue essa abordagem. Talvez seja, para esse professor menos complexo manter uma certa distância do aluno, pois não corre o risco de ser questionado durante as argüições, tornando-se detentor único do saber e dominador da situação, de forma que só resta ao aluno a opção de ser passivo e um mero repetidor do que lhe foi transmitido.

O desenvolvimento desta aula que retrataremos a seguir ilustra um professor de enfermagem que segue este modelo.

PROFESSOR - "Hoje a aula será sobre a importância e a técnica de lavagem das mãos, onde utilizarei este cartaz para que vocês possam visualizar e memorizar melhor os passos da técnica. (conteúdo preestabelecido pelo professor, exposição oral)

- Não me interrompam durante a explicacão ( ambiente austero, professor detentor do saber, aluno posição passiva)

ALUNO- interrompe fazendo uma pergunta sobre o cartaz....

PROFESSOR- Por favor não me interrompam, perguntas só no final (professor detentor do saber).

- Repitam a técnica agora até decorarem (aluno é um mero repetidor, processo ensinoaprendizagem ausente)

- Ah! é matéria para prova, eu quero que todos vocês decorem tudo. (constatação que o aluno assimilou se dá através de prova).

Através desse exemplo podemos verificar que o professor permanece como o detentor do saber, não permite aproximação do aluno e exige obediência e disciplina rígida. A ênfase dada é no conteúdo e não na pessoa. É claro que tal exemplo chega a ser uma caricatura desse professor mas, se fizermos uma reflexão nos lembraremos de vários exemplos em nossa vida escolar, e de situações em que atuamos com nossos pacientes e alunos dessa maneira. 
Observamos com freqüência professores queixandose que os resultados não foram satisfatórios e que não sabem porque os alunos não estão apreendendo os conteúdos efetivamente.

\section{ABORDAGEM COGNITIVISTA}

A abordagem cognitivista está ligada a processos organizacionais do conhecimento, suas formas, processamento, elaboração e tomada de decisão. Segundo MIZUKAMI (1986), esta teoria estuda cientificamente a aprendizagem como sendo um produto do meio ambiente, das pessoas ou de fatores externos ao aluno. Tem uma certa preocupação com as relações sociais, contudo dá maior ênfase à capacidade do aluno absorver as informações e processá-las.

Piaget é considerado um dos propulsores desta tendência. Segundo MALRIEU (1974), para Piaget a inteligência é uma ação que consiste na assimilação do real aos esquemas inatos ou adquiridos e da acomodação destes últimos aos fatos que resistem a esse processo de assimilação. Considera-se o indivíduo como um sistema aberto que vai se construindo a cada novo momento em busca cada vez do racional, da crítica, capaz de mudá-lo e ao meio onde vive.

MIZUKAMI (1986), refere que Piaget considera a existência de duas fases para a aquisição do conhecimento: Fase Exógena, que é a fase da constatação, da cópia, da repetição e Fase Endógena, que é a fase da compreensão das relações, das combinações. Acredita-se que o indivíduo adquire um determinado conhecimento quando ele está na fase endogena, ou seja, ele compreende, cria, tem pensamento reflexivo em relação ao conhecimento; é quando ele consegue coordenar as ações através de suas próprias atividades. Na verdade não se aprende nada relativamente novo, tudo já existe, apenas não era conhecido, observado, compreendido ou assimilado pelo indivíduo.

Dentro desta tendência o objetivo da educação não é a transmissão de informação, verdades ou demonstração, e sim que o aluno aprenda por si mesmo a verificar a veracidade destas informações e que ao mesimo tempo repense e as recrie de forma real, tendo como meta final a autonomia intelectual do aluno, assegurado pelo desenvolvimento de sua personalidade de instrumento lógico-racional.

A escola deverá oferecer ao aluno a possibilidade de aprender por si proprio, de investigar individualmente um determinado fato, através da motivação intrínseca, ou seja a fase endogena existe em cada um de nós.
Uma das diretrizes da escola Piagetiana é trabalho em grupo, onde situações são criadas para operacionalização de conceitos, de forma a proporcionar a reequilibração do aluno, ou seja quando ele realmente adquire um novo conhecimento e está maduro para a aquisição de outros mais complexos.

A relação professor-aluno deve ser horizontal, ou seja reciprocidade intelectual, cooperação moral e racional. Cabe ao professor evitar rotina, fixação de respostas e hábitos. As aulas devem ser dinâmicas, onde se propõe problemas sem contudo ensinar-lhes as soluções; provocar desafios. porém mantendo o autocontrole e a autonomia dos alunos; coordenar, orientar para que o aluno desenvolva suas capacidades da forma mais independente possível

Segundo MIZUKAMI (1986), o aluno deve ser tratado de acordo com sua fase evolutiva e o ensino deve ser adaptado conforme o seu desenvolvimento mental e social. Cabe ao aluno observar, experimentar, comparar, analisar e levantar hipoteses, sempre com o professor orientando para que ele explore os problemas, sem contudo dar-lhes respostas.

Para MALRIEU (1974), educar não é mostrar, é ensinar a inventar. O professor deve ser um orientador para os alunos, um instigador, fazendo com que os alunos aprendam por si mesmo, porém sem abandoná-los. Deve ser atento aos passos de aprendizagem dos alunos, propor-lhes questões, provocar situações onde os mesmos reflitam e estejam abertos para descobrir e apreender.

Nos últimos anos as escolas de enfermagem têm se reestruturado para várias mudanças no ensino, e destas ocorre a preocupação com a forma de ensinar e desenvolver o aluno.

Podemos constatar que o conhecimento já não é mais transmitido somente de forma vertical professor-aluno, mas de uma forma horizontal, o que implica o emprego de novas abordagens pedagogicas.

$\mathrm{Na}$ teoria cognitivista o aluno parte do senso comum e vai se estruturando, construindo seu saber. Talvez aqui podemos entrever uma relação ensinoaprendizagem na área de enfermagem, pois, o aluno quando chega a escola nada mais é que um iniciante dando seus primeiros passos para descoberta de novos conhecimentos, daí elaborando novas idéias

O ensino de enfermagem no decorrer do curso, leva o aluno a experienciar várias posições. Deve passar por um processo reflexivo abandonando velhos conceitos, construir o seu conhecimento a partir da observação, análise e desenvolvimento.

O professor de enfermagem já não é mais um transmissor de conhecimentos, onde ele apenas 
mostra e o aluno aprende de forma passiva, mas ele é um coordenador que propõe e evidencia situações, leva o aluno a observar, refletir e desenvolver suas idéias e adquirir outros conhecimentos.

Para exemplificar esta tendência dentro da enfermagem podemos imaginar uma aula sobre a técnica de lavagem das mãos.

PROFESSOR: Como conseqüência dos conhecimentos até agora adquiridos, podemos estudar hoje sobre a técnica da lavagem das mãos. (o professor mostra que o ensino aprendizagem é de acordo com os passos do conhecimento dos alunos conseqüência dos conhecimentos).

ALUNOS: lavagem das mãos? Mas isto parece aula de pré-primário onde se aprende higiene, como: escovar os dentes, lavar as mãos antes das refeições, etc.

PROFESSOR: Eu sei , mas vamos ver o que, além da higiene, está relacionado o lavar das mãos, a importância... (professor incita os alunos a refletir, pensar e descobrir novos conhecimentos a partir dos que já tem).

ALUNO: Ah! já sei precisamos lavar as mãos para não levar doenças para os pacientes.

PROFESSOR: S6 isto? temos muito mais a descobrir e falar da lavagem das mãos, tentem descobrir, façam grupos, procurem maiores informações e tragam para discutirmos na próxima aula, estarei a disposição para dúvidas. (professor induz os alunos a procura por novos conhecimentos e não ficar apenas no senso comum, a espera de que tudo lhes seja transmitido passivamente).

ALUNOS: se dividem em grupos, vão pesquisar e discutem sobre o assunto.

$\mathrm{Na}$ aula seguinte, professor e alunos discutem e os alunos mostram ao professor o que adquiriram de informações.

PROFESSOR: Vamos analisar o seguinte caso: Um auxiliar de enfermagem é escalado para fazer os curativos cirúrgicos de 3 pacientes pós operados na unidade de clinica cirurgica. Ele prepara todo o material, calça as luvas e inicia o procedimento com o $1^{\circ}$ paciente, a seguir com o $2^{\circ}$ e da mesma forma com $03^{\circ}$ paciente. Ao término de todos os curativos ele procede a limpeza do material, lava as mãos e faz suas anotações. O que você acha desta situação? (Propondo uma situação real e através da discussão do problema apresentado, os alunos vão construir o seu próprio conhecimento).

ALUNOS A: Bom professor, eu acredito que o auxiliar está agindo de forma incorreta pois ele deveria ter lavado as mãos entre um paciente e outro, trocado de luvas, pois da forma como agiu ele está expondo todos os 3 pacientes à infecção hospitalar.
ALUNO B: Podemos pensar que ele acredita não ser necessário lavar as mãos por estar usando luvas, o que é muito comum acontecer por falta de conhecimento (alunos demonstram estar compreendendo o significado e importância do procedimento assim como resgatam o que haviam pesquisado)

Após várias discussões sobre a situação...

PROFESSOR: Agora vocês ainda acham que lavagem das mãos é assunto somente de préprimário?

ALUNOS: Não, já sabemos que necessitamos lavar as mãos antes de cuidar de cada paciente, antes de várias atividades.

PROFESSOR: Muito bem e o que mais, com o que vocês relacionam a não lavagem das mãos?(professor instiga os alunos a falarem mais e analisar, fazer correlações).

ALUNOS: Sabemos que a não execução da técnica da lavagem das mãos pode levar ao aumento das infecções e que deve ser realizada corretamente..

Os alunos através da investigação e problematização conseguiram aprender por si mesmo, e o professor foi apenas fazendo orientações para que eles próprios refletissem e adquirissem os conhecimentos necessários. Nessa abordagem observamos que o professor incita os alunos a procurarem o conhecimento, a refletirem em relação a uma situação e a chegarem às próprias conclusões.

\section{ABORDAGEM COMPORTAMENTALISTA}

Esta teoria baseia-se fundamentalmente, no empirismo, primando pela observação do mundo real. "As ações humanas e toda natureza são comparáveis a uma máquina enorme operando de acordo com leis mecanicistas" (GOODING; PITTENGER, 1977).

O homem é visto como produto do meio e sujeito às contingências deste, o conhecimento derivado da realidade externa já estava presente e é uma descoberta (MIZUKAMI,1986).

Para os comportamentalistas, também denominados behavioristas, a experimentação planejada é o alicerce do conhecimento, ou seja, a experiência determina o conhecimento. Segundo MIZUKAMI (1986), "a ciência consiste numa tentativa de descobrir a ordem na natureza e nos eventos".

Aindla segundo MIZUKAMI (1986), o estudioso contemporâneo desta abordagem é Skinner, psicólogo americano, segundo o qual "cada parte do comportamento é uma função de alguma condição 
que é descritível em termos físicos, da mesma forma que o comportamento". Para ele o comportamento é resultante do condicionamento operante, onde uma resposta desejada torna-se mais provável ou mais freqüente quando reforçada. Skinner considera que o aluno e neutro e recipiente de informações, desenvolvendo modelos que implicam recompensa e controle, direcionados para os aspectos observáveis e mensuráveis da educação.

Os comportamentalistas consideram que o ambiente pode ser alterado e em conseqüência alterar-se o comportamento.

Do ponto de vista educacional deve-se transmitir conhecimentos, habilidades, comportamentos por meio da experimentação. Os modelos são estruturados e controlados de forma a atingir os objetivos propostos. Para que isso ocorra são necessários os reforços que podem ser positivos de forma a se condicionar o aluno a apresentar respostas ou comportamentos desejáveis, ou negativos para levar à extinção uma resposta indesejável apresentada pelo aluno.

Ao professor cabe planejar, estruturar e controlar os meios pelos quais se deseja atingir os objetivos propostos. Os reforços, podem ser, por exemplo: notas, elogios, distinções e prestígio.

Uma forma de exemplificar a estruturação do ensino, nesta abordagem, seriam os estudos programados, bastante difundidos em nosso meio. A divisão de temas abrangentes em pequenos módulos seqüencialmente aplicados, levariam o indivíduo à aquisição de habilidades e comportamentos mais complexos.

A abordagem comportamentalista busca aplicar os conhecimentos científicos à educação, que é tratada tecnologicamente, os objetivos a serem atingidos pressupõem a determinação prévia do que se deseja ensinar, até que ponto se pretende que o aluno aprenda e a quais condições se deseja que o aluno responda.

$O$ processo ensino-aprendizagem não pressupõe a participação do aluno na decisão do que aprender e o controle dos meios é total por parte dos que decidem, o que evidencia a posição de que o que não foi planejado não é desejado.

Sendo condicionamento operante "o processo de aprendizagem pelo qual uma resposta torna-se mais provável ou mais freqüente; assim denominado porque opera sobre o ambiente e gera mudanças" BIGGE (1977).

Observamos que um operante - seqüência de atos ou comportamento, são reforçados, aumentando a probabilidade de certas respostas se repetirem; neste sentido, as respostas operantes são modificadas ou substituídas conforme planejado anteriormente.
O indivíduo, segundo esta abordagem, determina sua visão com base nas conseqüências que se seguiram a um comportamento semelhante no passado, assim dirigindo-se os reforços no sentido do comportamento desejado obtém-se a aprendizagem intencionada.

Nota-se que, nesta abordagem, as interações do indivíduo com o meio, decorrentes de suas percepções, impulsos e outras situações não mensuráveis e observáveis não são considerados. $E$ bem verdade, no entanto, que o ensino nesta abordagem pode ser individualizado, na medida em que se particulariza o evento reforçador para se obter o aprendizado planejado.

No tocante à enfermagem, podemos sugerir que o condicionamento operante se faz presente no ensino das técnicas e procedimentos de enfermagem. Uma seqüência de passos são programadas para que se atinja a habilidade esperada no desempenho da função objetivada.

As aulas em laboratórios de técnicas de enfermagem visam treinar os alunos, passo a passo, num ambiente especialmente preparado para esse fim e, portanto, controlado pelo professor que determina os reforços necessários para o aprendizado programado.

Com isso, pode-se notar que comportamentos indesejáveis são extintos, cedendo lugar aos considerados adequados e pertinentes.

O mesmo pode ser observado nos campos de estágio, onde os alunos podem exercitar o que aprenderam e receber reforcos adicionais e adequados a esta etapa subsequente, consolidando $o$ aprendizado desejado.

A fim de compreendermos melhor estas colocações imaginemos a seguinte cena:

PROFESSOR- Hoje vamos aprender a técnica de preparo de medicação injetável IM. Para isto devemos seguir os seguintes passos:

1.Verificar a prescrição

2.Solicitar e conferir a medicação

3.Preparar com técnica asséptica conforme prescrito

4.Colocar em uma bandeja com bolas de algodão e álcool.

5.Verificar a identificação do paciente

6.Fazer assepsia da pele

7.Administrar em ângulo de $90^{\circ}$ no músculo escolhido

8. Retirar a agulha

9. Comprimir o local com bola de algodão.

Verificamos aqui que a situação é dividida em etapas seqüenciais, o indivíduo deve segui-las a fim de obter o resultado desejado. 
Os reforços são dados pelo professor durante o procedimento e ao término deste, sob formas variadas - do elogio a notas propriamente ditas.

Aqui ficou evidente para nós que a preocupação do professor é fazer o aluno aprender determinada técnica através da memorização. Com o detalhamento dos passos de uma tarefa, cada etapa necessariamente se apoia na subsequente para facilitar a compreensão e a execução pelo aluno. Só é permitido ao aluno seguir para a próxima etapa quando consegue êxito na anterior.

Nos laboratorios de técnicas de enfermagem, onde os alunos se exercitam, é freqüente verificarmos os ensaios dos alunos no desempenho de procedimentos, passo a passo, até adquirirem habilidade necessária ao mesmo.

O papel do aluno limita-se ao recebimento das informações, reprodução dos passos da experiência até obtenção do resultado final com êxito.

O professor controla o ambiente e os reforços. A avaliação da aprendizagem é através da observação da modificação do comportamento no sentido planejado.

\section{ABORDAGEM HUMANISTA}

Nesta tendência o enfoque central é o aluno. Os estudiosos que representam as idéias centrais dessa abordagem são Carl Rogers e A. Neill. Segundo MIZUKAMI (1986), para eles a ênfase se dá nas relações interpessoais e no crescimento que delas resulta, centrado no desenvolvimento da personalidade do indivíduo. O professor em si não transmite conteúdo, dá assistência, sendo um facilitador da aprendizagem. O conteúdo advém das próprias experiências dos alunos, assim o professor não ensina: apenas cria condições para que os alunos aprendam.

Para LIBÂNEO (1982) “A ênfase que esta tendência põe nos processos de desenvolvimento das relações e da comunicação torna secundária a transmissão de conteúdos. Os processos de ensino visam facilitar aos estudantes os meios para buscarem por si mesmos os conhecimentos que, no entanto, são dispensáveis".

Rogers, segundo MIZUKAMI (1986), afirma que a experiência pessoal e subjetiva é o fundamento sobre o qual o conhecimento é construído, no decorrer do processo de vir-a-ser da pessoa humana. Ao experienciar o homem conhece, portanto a experiência constitui um conjunto de realidades vividas por ele.

Ainda segundo Rogers, o único homem que se educa é aquele que aprendeu como aprender. Fica muito irritado com a idéia de que o estudante deva ser "motivado", afirma que o jovem é intrinsecamente motivado, em alto grau, porém com o passar do tempo torna-se amortecido. Assim, o papel do professor como facilitador da aprendizagem é a de suscitar essa motivação, descobrir que desafios são reais para o jovem e proporcionar-lhe a oportunidade de enfrentá-los.

A escola deve oferecer condições que possibilitem a autonomia do aluno, respeitá-lo tal como é para que ele possa se desenvolver. Segundo LIBÂNEO (1982), é acentuado o papel da escola na formação de atitudes, portanto, deve estar mais preocupada com os problemas psicologicos do que com os pedagogicos ou sociais.

ROGERS(1978) considera que algumas qualidades do professor são essenciais para facilitar a aprendizagem, como a autenticidade, o professor deve ser sempre uma pessoa real nos contatos com seus alunos, ser para seus alunos uma pessoa, não a corporificação sem feições irreconhecíveis, de uma exigência curricular. Quando o professor se encaminha para um encontro pessoal direto com o aprendiz, encontrando-se com ele na base pessoapessoa significa que está sendo ele próprio.

Outra qualidade é o apreço, aceitação e confiança no aprendiz. É interessar-se pelo aprendiz, mas um interesse não possessivo, é a aceitação de um outro indivíduo, uma pessoa separada, cujo valor próprio é um direito seu. Relatos de estudantes que viveram tais experiências reforçam essa idéia, muitos dizem que sentiam-se importantes, maduros e capazes de fazerem as coisas por si mesmo.

A qualidade que estabelece clima de aprendizagem auto-iniciada, experiencial, é a compreensão empática . Para o autor, é quando o professor tem a habilidade de compreender as reações íntimas do aluno, quando tem a percepção sensível do modo como o aluno vê o processo de aprendizagem significativa. É a atitude de estar no lugar do outro, de ver pelos olhos do aluno, quando isso ocorre, verifica-se um enorme efeito de libertação.

Desta forma, para ROGERS (1978), o processo de ensino irá depender do caráter individual do professor, como ele se inter-relaciona com o caráter individual do aluno. Não é possível especificar as competências de um professor, pois elas dizem respeito a uma forma de relacionamento de professor e aluno, que sempre é pessoal e única.

$O$ relato da Caracterização da Disciplina de Enfermagem Pediátrica da EEUSP, pelos docentes da referida disciplina, é um exemplo de experiência de ensino na enfermagem que contempla essa opção pedagogica. Segundo BONILHA et al.(1990), as docentes pretendem oferecer ao aluno uma proposta que "combine o lógico e o intuitivo, o intelecto e o 
sentimento, o conceito e a experiência, a idéia e o significado, num processo continuo." Ainda afirmam que "a disciplina possui como característica fundamental, ser centrada no estudante" e que," o propósito do curso não é apenas aprender sobre a matéria, mas aprender essa matéria como pessoas inteiras".

Assim, desenvolvem o conteúdo através de estratégias que possibilitam ao aluno a familiaridade, o conhecimento, a compreensão e a aplicação do conteúdo. Isto pode ocorrer através de preleções, observações, demonstrações, ensino de campo e leituras.

Para o desenvolvimento pessoal, as estratégias utilizadas são aquelas que facilitam o contato e a percepção do aluno ao próprio processo de aprendizagem. São realizados contatos no decorrer do curso com a finalidade de possibilitar reflexões sobre as experiências ocorridas, motivações e dificuldades.

No nosso grupo de discussão nenhum dos participantes desenvolveu uma experiência nesse referencial. Observamos, pelas leituras e relatos de professores e alunos, que ela realmente favorece 0 aprendizado e o desenvolvimento da pessoa, do ser humano, tanto do aluno quanto do professor.

Numa tentativa de exemplificar como seria esta abordagem e facilitar sua compreensão na prática da enfermagem, propomos imaginar a seguinte cena:

PROFESSOR: - "Nas atividades de hoje vamos discutir as formas de abordagem à criança, e eu gostaria de propor para iniciarmos, um debale sobre a questão. O que vocês acham?(nota-se a preocupação em perceber a motivação dos alunos, a capacidade de ser empático, colocando-se no lugar dos alunos, e verificando o que acham da sua proposta)

Os alunos reagem de forma positiva, dando ao professor a dica para continuar..

PROFESSOR_Observo que vocês estão dizendo sim, é isso? ( procura validar sua percepção )... então vamos começar. Qual a idéia que vocês têm sobre o que é ser criança? Alguém gostaria de começar a falar? (estimulando a discussão e a percepção dos conhecimento prévios dos alunos, assim fortalece o auto conhecimento e parte daquilo que o aluno quer aprender, ajudando-o a descobrir o próprio caminho).

PROFESSOR_ Vocês podem se lembrar de algum momento vivenciado por vocês ou por pessoas próximas e que poderiam estar trazendo para nossa discussão? (considerando a importância de discutir o tema, o professor se coloca em posição de igualdade com os alunos, empenha- se em organizar e tornar facilmente disponiveis recursos)

Os alunos demonstram interesse durante as discussões e o professor segue a proposta da aula, sempre discutindo e trocando experiência com eles... (ouvindo a opinião e tomando decisão em conjunto o facilitador estabelece o clima do grupo, conta com o desejo do aluno de realizar os propósitos que têm sentido, para cada um, como força de motivação subjacente à aprendizagem significativa.)

Ao término das apresentações e após a discussão do grupo, o professor facilitador faz uma reflexão junto com os alunos sobre a experiência vivida, em relação ao conteúdo trabalhado, tentando apreender o significado para os alunos. A impressão do grupo de alunos e do professor é que o resultado do encontro foi positivo e houve um aprendizado significativo.

Nossa impressão é que nessa abordagem o aluno torna-se mais responsável e adquire mais autonomia, ele é respeitado enquanto pessoa. Como o professor se coloca numa posição horizontal, preocupado com o aluno, que está vivenciando situações, não há temor por parte do aluno em se expor, permitindo que o mesmo esclareça suas duvidas e haja crescimento.

\section{ABORDAGEM SÓCIO-CULTURAL}

A abordagem sócio-cultural ou libertária elimina pela raiz as relações autoritárias, onde não há escolas nem professor, mas círculos de cultura e um coordenador cuja tarefa essencial é o diálogo. O educador, cujo campo fundamental de reflexão é a consciência do mundo, cria, não obstante, uma pedagogia voltada para a prática histórica real.

Segundo FREIRE (1975), o educador e educando são sujeitos de um processo em que crescem juntos, porque ninguém educa ninguém, ninguém se educa; os homens se educam entre si, mediatizados pelo mundo. $\mathrm{O}$ coordenador jamais influi ou impõe, a participação dos educandos é livre e crítica. O diálogo é a essência desta educação.

A relação professor e aluno é horizontal e não imposta. O homem assumirá a posição de sujeito de sua própria educação e, para que isto ocorra, deverá estar conscientizado do processo.

O professor procurará desmitificar e questionar com o aluno, a cultura dominante, valorizando a linguagem e cultura deste, criando condições para que cada um deles analise seu contexto criando cultura. Somente através do diálogo será possível democratizar a cultura. 
$O$ representante mais significativo da abordagem libertária é Paulo Freire, com o método de alfabetização de adultos. Neste método a codificação inicial consiste numa espécie de figura, um desenho representativo de uma situação existencial real ou construída pelos alunos. Ao elaborar esta representação os alunos realizam uma operação de distanciamento do objeto cognoscível. Desta forma, professor e alunos poderão refletir conjuntamente de forma crítica sobre os objetos que os mediatizam.

Através do debate desta situação em que se discute o homem como um ser de relações, se chega a distinção de dois mundos - o da natureza e o da cultura. Percebe-se então a posição normal do homem como um ser no mundo e com o mundo. Como um ser criador que, através do trabalho, vai alterando a realidade. Na discussão da situação dos elementos que se repetem, emergem dois conceitos básicos: o da necessidade e o do trabalho e, a cultura se explica no primeiro nível, o de subsistência.

O método de FREIRE $(1975,1983)$ consiste das seguintes fases:

- levantamento do universo vocabular dos grupos com quem se trabalha;

- escolha das palavras geradoras;

- criação de situações existenciais típicas do grupo que será alfabetizado;

- criação de fichas roteiro;

- elaboração de fichas com a decomposição das famílias fonéticas correspondentes aos vocábulos geradores

- ficha de descoberta, contendo as famílias fonêmicas, que é utilizada para a descoberta de novaspalavras.

Na medida em que os alunos participam ativamente da exploração de suas temáticas, sua consciência crítica da realidade se aprofunda.

Apesar de intimamente ligada à educação de adultos, ao processo de alfabetização de adultos, a abordagem de Paulo Freire considera a educação como um processo contínuo de tomada de consciência e de modificação de si próprio e do mundo, o que tem profundas implicações no ensino de $1^{\circ}, 2^{\circ}$ e $3^{\circ}$ graus.

A alfabetização é a conseqüência de uma reflexão que o homem começa a fazer sobre sua própria capacidade de refletir. Sobre sua posição no mundo, sobre o mundo mesmo, sobre seu trabalho, seu poder de transformar o mundo. Sobre o encontro das consciências. Reflexão sobre sua própria alfabetização, que deixa assim de ser algo externo ao homem, para ser dele mesmo. Para sair de dentro de si, em relação com o mundo, com uma criação. na medida em que, implicando em todo este esforço de reflexão do homem sobre si e sobre o mundo em que e com que está, o faz descobrir "que o mundo é seu também, que o seu trabalho não é a pena que paga por ser homem, mas um modo de amar - e ajudar o mundo a ser melhor."

O professor de enfermagem pode estar utilizando esta abordagem para desenvolver o ensino das matérias do curso pois, permite que o aluno compreenda por si os fatores socio-culturais da clientela a ser assistida contribuindo apara a formação de consciência crítica.

Um exemplo desta abordagem na prática da enfermagem é o Programa de Formação de Pessoal de Nível Médio para o Setor Saúde do Ministério da Saúde (1989) que "vem construindo com bases legais e pedagogicas, uma alternativa adequada e coerente para a qualificação de sua força de trabalho."

Segundo este Programa "o sujeito que aprende é cicladão social e historicamente determinado, está inserido na produção de serviços de saúde, tem como atividade principal o trabalho e, apesar da heterogeneidade de sua formação prévia, inserção social, funções que exerce, relações de poder e hierarquia, é um sujeito apto a adquirir e produzir conhecimentos."

Tentando exemplificar podemos imaginar uma cena em que o professor trabalha o conteúdo de alimentação.

PROFESSOR_ "Na nossa aula de hoje iremos discutir sobre esta figura ( mostra a figura que contempla fenômenos da natureza, plantações, rios, frutas e crianças sadias e desnutridas). Projetada a primeira palavra geradora, representação gráfica da expressão oral da percepção do objeto, inicia-se o debate em torno de suas implicações.

\section{Ex: Palavra geradora- COMIDA}

Aspectos para discussão: Desnutrição/ Fomedo plano local ao nacional

Mortalidade Infantil e doenças derivadas.

Utilização adequada dos alimentos

( Professor e alunos refletem conjuntamente de forma crítica sobre os objetos que os mediatizam)

ALUNO A: Olha professor, recentememte eu lí numa revista questões sobre a fome e distribuição de alimentos que eu considero super importante para nós estarmos compreendendo essa situação e o porquê de ter chegado nesse ponto, em um país tão grande e com tanta produção de alimentos...

Com a discussão fomentada pelo coordenador volta a visualização da palavra 
geradora-COMIDA- e agora discute-se os dois mundos, o da cultura e o da natureza, fazendo emergir dois conceitos básicos: necessidade e trabalho.

A discussão continua e os temas vão emergindo...

Professor ( finalizando). Através da nossa discussão pudemos perceber quanto a cultura, as formas de utilização do alimento assim como as questões que envolvem uma política de distribuição de renda e condiç̃es sócio-econômicas determinam a situação de vida das pessoas e a morbimortalidade infantil. Evidenciou o quanto nós profissionais podemos estar atuando neste processo. É importante uma reflexão de cada um sobre o problema e a forma que podemos estar participando para a resolução.

Como a preocupação nessa abordagem é com cada aluno em si, com o processo e não com o produto de aprendizagem acadêmico padronizado, percebemos que permite a aquisição de conhecimento e de espírito crítico do grupo de alunos e professor.

\section{CONSIDERAÇÕES FINAIS}

Sabemos que não existe um professor que se mantenha sob a orientação de uma única tendência. Em geral há uma mistura de várias tendências pedagógicas em um único professor, porém consideramos que é importante que o professor siga uma determinada diretriz para que haja coerência entre sua prática e seu discurso.

Concordamos com a afirmação de BIGGE (1977), "um professor sem sólida orientação teórica dificilmente consegue ir além de manter os alunos ocupados", sendo corroborada por GOODING;PITTENGER (1977) ao sugerir que sem uma base racional coerente a atuação do professor será interpretada como confusa e perturbadora.

Desta forma, consideramos que o conhecimento das diversas tendências pedagógicas permite ao professor refletir sobre suas crenças e valores e assim, fazer uma opção por aquela ou aquelas que melhor correspondam com seus próprios pressupostos.

Segundo Dr ${ }^{a}$ Elza Garrido, professora da F.E.USP, em aula apresentada na disciplina, o professor precisa mudar de atitude em relação aos alunos, aos conteúdos ensinados e ao processo pedagógico. A melhor tendência pedagógica é aquela que permite fazer uma educação transformadora dos sujeitos nele envolvidos, ou seja, professor e aluno. Para ela o construtivismo é a forma que permite o aluno construir seu aprendizado, sem que apenas 0 receba passivamente.
Cabe ao professor utilizar todos os recursos disponíveis para facilitar o aprendizado, fazendo com que seus alunos reflitam criticamente e construam seu proprio saber

Quanto ao futuro da escola e do professor concordamos com as afirmações de Bill Gates apud PAZZEMBOM (1996) "ao contrário de outras profissões, o futuro do magistério parece extremamente promissor", mas apenas "os educadores que trouxerem energia e criatividade para sala de aula prosperarão" e ainda "os computadores e os programas educativos não vão substituir o professor. O papel mais importante continua e sempre continuará a ser do professor ou do mediador".

O professor precisará estar capacitado, com bases teóricas firmes que o possibilitem participar como orientador do aluno, ajudá-lo a aprender a aprender, fazendo com que o aluno construa seu próprio conhecimento.

Partindo do princípio de que o professor de enfermagem, na graduação, ensina para uma maioria de jovens, alguns ainda adolescentes, seu trabalho não pode ser rotineiro, nem se contentar em repassar conteúdo. Ele não pode ser apenas um bom técnico, mas estar plenamente capacitado para o ensino, que é muito mais do que apenas a transmissão de conhecimentos.

$\mathrm{Na}$ verdade, o professor de enfermagem precisa se instrumentalizar teóricamente para realizar satisfatoriamente seu trabalho como docente, criar sua propria didática, ou seja, sua própria prática de ensino em situações específicas, de acordo com o contexto social em que atua, tornando a aprendizagem de enfermagem vinculada a realidade. Desta forma, pode oferecer um ensino onde promova o crescimento e desenvolvimento das capacidades cognitivas e afetivas dos seus alunos, e também favorecer que os mesmos desenvolvam espírito crítico-reflexivo em relação às questões da nossa profissão.

Acreditamos que as escolas de enfermagem têm, já a algum tempo, iniciado o processo de reflexão crítica sobre seu próprio trabalho, preocupadas com a qualidade do ensino oferecido, com a formação de profissionais e de futuros professores. Tal reflexão, segundo BORDAS (1996), "significa repensar o ato de ensinar enquanto ato pedagógico, ou seja, ato que tem um sentido éticopolítico, um sentido epistemologico diante do conhecimento e um sentido relacional de interação entre subjetividades distintas".

Esperamos que através da leitura e reflexão sobre as diferentes tendências pedagógicas seja possível, ao enfermeiro, ampliar seus conhecimentos na área do ensino e facilitar escolhas apropriadas para utilização tanto na sua prática profissional quanto nas relações pessoais. 


\section{REFERÊNCIAS BIBLIOGRÁFICAS}

BIGGE, M.L. Teorias da aprendizagem para professores. Sao Paulo, EPU/EDUSP, 1977.

BONILHA, A.L.L. et al. Caracterização da disciplina enfermagem pediátrica da Escola de Enfermagem da USP. Apresentado no Fórum de Debates sobre o Ensino de Graduação de Enfermagem da USP, Såo Paulo, 1990.

BORDAS, M.C. Apresentação. In: MORAES,V.R.P.M. Melhorias do ensino e capacitação docente. Porto Alegre, UFRGS,1996. p. .

BRASIL. Ministério da Saúde. Secretaria Geral. Secretaria de Modernizaça Administrativa e Recursos Humanos. Capacitação pedagógica para instrutor/supervisor área da saúde. Brasília, 1989.

FREIRE, P. Educação como prática da liberdade. Rio de Janeiro, Paz e Terra, 1983. 1975

Pedagogia do oprimido. Rio de Janeiro,Paz e Terra,

GOODING, C.T.; PITTENGER, O.E. Teorias da aprendizagem na prática educacional. Sáo Paulo, EPU/EDUSP, 1977.
LIBÂNEO, J.C. Tendências pedagógicas na prática escolar. Rev. Ande, n. 6, p.11-9. 1982.

MALRIEU, P. Influências das teorias psicológicas sobre a pedagogia. In: BESSE, M.; MIALARET,G. Tratado das ciências pedagógicas. São Paulo, EDUSP, 1974. p.76-9.

MIZUKAMI, M.G.N. Ensino: as abordagens do processo. São Paulo, EPU/EDUSP 1986.

MORAES,V.R.P (0rg.). Melhoria do ensino e capacitação docente. Porto Alegre, UFRGS,1996

PAZZEMBOM, W. Uso da informática ainda está em desenvolvimento. Folha de São Paulo, São Paulo, 10 set. 1996. Suplemento especial, p.6-7.

ROGERS, C.R. Liberdade para aprender . 4.ed. Belo Horizonte, Interlivros, 1978.

SAVIANI, D. Escola e democracia . São Paulo, Cortez, 1985.

SNYDERS, G. Pedagogia progressista: para onde vão as pedagogias nao-diretivas? Lisboa, Morais, 1974. 